Intersections

Canadian Journal of Music

Revue canadienne de musique
Intersections

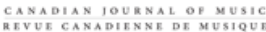

\title{
Crossing the Rubicon: Debussy and the Eternal Present of the Past
}

\section{Gregory Marion}

Volume 27, numéro 2, 2007

URI : https://id.erudit.org/iderudit/1013112ar

DOI : https://doi.org/10.7202/1013112ar

Aller au sommaire du numéro

\section{Éditeur(s)}

Canadian University Music Society / Société de musique des universités canadiennes

\section{ISSN}

1911-0146 (imprimé)

1918-512X (numérique)

Découvrir la revue

Citer cet article

Marion, G. (2007). Crossing the Rubicon: Debussy and the Eternal Present of the Past. Intersections, 27(2), 36-59. https://doi.org/10.7202/1013112ar
Résumé de l'article

Cet article veut démontrer l'évidence de l'hétéroglossie - processus de connaissance de sa langue maternelle par le biais d'autres langues - de Mikhaïl Bakhtin dans deux compositions tirées des Children's Corner de Debussy, à savoir le « Golliwogg’s Cake-Walk » et, plus subtilement que dans le précédent, dans la "Serenade for the Doll ». La "Sérénade " comprime un certain nombre d'horizons historiques - certains wagnériens - au fil du développement d'un style original par Debussy. Son approche reflète l'obsession qu'entretient La belle Époque avec le passé dont elle ressent le besoin de conserver vivant tout en proposant un futur se retrouvant à travers le mélange de voix multiples.
Copyright @ Canadian University Music Society / Société de musique des universités canadiennes, 2008
Ce document est protégé par la loi sur le droit d'auteur. L'utilisation des services d'Érudit (y compris la reproduction) est assujettie à sa politique d'utilisation que vous pouvez consulter en ligne.

https://apropos.erudit.org/fr/usagers/politique-dutilisation/ 


\title{
Crossing the Rubicon: Debussy and the Eternal Present of the Past
}

\author{
Gregory Marion
}

The hidden harmony is better than the obvious.

Pablo Picasso

Interest in the past increased dramatically during La belle Epoque in two regards: the past became both the subject of interrogation and a vehicle for future exploration. Access to the future, in other words, was sought through confrontation with the past. ${ }^{1}$ Debussy participated fully in this activity by subjecting past musical practices to subtle but profound revisions. ${ }^{2}$ His music is a deeply wrought fusion of historical horizon and future orientation. This study focuses on such a fusion in two short compositions by Debussy. In particular, the study examines "Serenade for the Doll" from the collection entitled Children's Corner (1908) where old and new compositional approaches are mediated by Debussy's response to a spectre from his immediate past-Wagner. To begin, however, passages from "Golliwogg's Cake-Walk," the closing work in the same collection, are considered. ${ }^{3}$

As a theoretical framework, Mikhail Bakhtin's concept of heteroglossia-the concept of coming to know one's own language in the language of others-will be applied to the study of the two works in question. In the "Serenade" in particular, Debussy collapses a number of historical horizons as he pursues his own compositional path, which, of course, is entirely congruent with the historical interests of $L a$ belle Epoque. Said in another way, Debussy keeps the past vividly

1 Kern (1983) addresses among other topics the novel ways in which the era conceptualized time and space both in the arts and the sciences, with reference to Picasso, Proust, Perry and Bergson. Galison (2003) speaks to similar matters in cultural terms, though from a scientific perspective centered upon the contributions of Einstein and Poincaré.

2 As did Satie, Ravel, and early Stravinsky-which is to mention nothing of the advent of neoClassicism in France, as explored by Messing (1988).

3 Written for his daughter Chouchou, Children's Corner was one among many collections in the genre of children's music composed in France during Debussy's lifetime. Taken at face value, works such as Faurés Suite Dolly (piano four hands, 1894-97), Ravel's Ma mère l'Oye (piano four hands, 1908-10), and even Debussy's own La boite d joujoux (piano score 1913, later in ballet version) were considered accessible to young audiences. Audience reception is not at issue, however, in this article. I wish to thank an anonymous reader for helpful suggestions concerning the contextualization of Children's Corner from the perspective of la jeunesse. (Debussy's spelling of "Golliwogg" is employed throughout, even if the noun is more commonly spelled "Golliwog.") 
alive through heteroglossia, while fashioning a radically novel style predicated upon the blending of multiple voices.

\section{Debussy AND his Wagnerian Past}

The past is felt in Debussy in a host of ways, including an early obsession with "Wagner the Precursor" that cooled eventually into a lifelong ambivalence. ${ }^{4}$ This ambivalence took on a number of forms, among them Debussy's proclivity for self-promotion, discernible on one level in French nationalism and his adopted moniker, "Claude Debussy, musicien français," and on another in the knowledge of what it means to be a latecomer after a Wagnerian precursor. This ambivalence is made particularly clear in an article entitled "German Influence on French Music," written for Le Mercure de France in 1903, which sounds a cautionary note concerning both the role and the definition of influence in the arts. According to Debussy, overinvestment in the concept of influence venerates the contribution of the earlier artist at the expense to the latecomer. ${ }^{5}$ Debussy pursues the point as follows:

German influence never had any ill effect on anyone except those ... who take the word "influence" to mean "imitation."

Besides, it is always difficult to be precise about influences, whether it is of Goethe's second Faust or of Bach's B Minor Mass. These works will remain monuments of beauty, unique and incapable of repetition. Their "influence" is like that of the sea or the sky, universal rather than especially German.

Closer to our own time, is not Wagner perhaps an example of the subjugator? However, musicians should be grateful to him for having left us [Parsifal] an admirable treatise on the uselessness of set forms ... a masterly contradiction of all that is in the Ring.

Wagner, if one may be permitted a little of the grandiloquence that suits the man, was a beautiful sunset that has been mistaken for a sunrise. There will always be periods of imitation and influence, but one can never foresee how long they will last, still less their nationality; truth moves at the same speed as the laws of evolution. (Debussy 1977, 83)

4 On the topic of Wagner in Debussy, see Holloway (1979) and Abbate (1981); for recent studies see Donnellon (2003), and DeVoto (2004 [see especially Chapter 2 "Aural images: Debussy's recycling"]). Whether in early-period works such as the song "Beau Soir" (1882-83), middle-period works such as Pelléas et Mélisande (1902), or late-period works such as En blanc et noir (1915), Debussy never fully exorcised the "ghost of old Klingsor"-a point that Schoenberg $(1975,172-173)$ deftly identified as early as 1931 .

5 On first impression, Debussy's engagement with Wagner appears to align well with what Harold Bloom identifies as the "anxiety of influence": "influence, as I conceive it, means that there are no texts, but only relationships between texts. These relationships depend upon a critical act, a misreading or misprision, that one poet performs upon another, and that does not differ in kind from the necessary critical acts performed by every strong reader upon every text he encounters." (Bloom 1975, 3) In the late nineteenth and early twentieth centuries, the influence exerted by Wagner upon France was palpable well beyond the musical world, with Baudelaire and others trumpeting Wagner's Gesamtkunstwerk. (Witness the 1885 birth of the Parisian literary journal La revue wagnérienne.) Bloom's theories are applied to music by Klein (2005), Korsyn (1991), Straus (1990), and Abbate (1981). 
While this statement can be read in any number of ways-as vitriolic, barbed, and even masterfully satirical-it reveals the complexity of Debussy's attitude toward Wagner. One theme, however, looms large in his essay, the theme of influence. The term held a radically new meaning not only for Debussy but more generally for later nineteenth- and early twentieth-century intellectuals of differing ilk. ${ }^{6}$

\section{BAKHTIN AND HeTEROgLOSSIA}

In the early 1900s, the Russian literary critic Mikhail Bakhtin tackled this new meaning of influence head-on, claiming that no speaker is "the biblical Adam, dealing only with Virgin ... objects, giving them names for the first time" (Bakhtin 1986, 93). According to Bakhtin's notion of influence, an author amalgamates a multitude of voices, past and present. This "take" on influence differs from the familiar sense of the term wherein one confronts the past so as to move beyond it. Bakhtin's notion collapses historical barriers. The point is central to Bakhtin's definition of "heteroglossia" - the incorporation of "another's speech in [one's own] language" (Bakhtin 1981, 324). According to Bakhtin's concept of heteroglossia, all communicative acts depend upon the fusion of horizons (especially past and present) so critical to the mindset of Debussy's era. ${ }^{7}$ His era increasingly understood that every artistic and scientific act is populated by a polyphony of voices-heteroglossia. Consider, for instance, the pre-Raphaelite movement in art spearheaded by Dante Gabriel Rossetti (1828-1882). To its cult of realism, the movement added Arthurian legend mixed with classical Greek overtones, and thus expressly collapsed historical barriers. ${ }^{8}$

The contextualization of the past, so prevalent in Debussy's era, aligns well, then, with Bakhtin's concept of heteroglossia. Broaching the matter from the perspective of the novel, Bakhtin in effect speaks of nested languages and horizons, and then of an eternal present in the past. The operant terms here are otherness, horizon, and language, terms to which we shall return:

What is realized in the novel is the process of coming to know one's own language as it is perceived in someone else's language, coming to know one's

6 In addition to Bloom, Klein, Korsyn, Straus, and Abbate see Orledge (2003), and McFarland (2000). The latter explore the topic of influence in Debussy, though from a perspective quite different than the one I advocate here.

7 Jameson (1981 [especially his Chapter 1]) conceives the fusion of horizons in slightly different terms, albeit terms that resonate with Bakhtin. Jameson's proposition of "a single great collective story... grasped as vital episodes in a single vast unfinished plot" (19-20) is central to his conviction that all writing is a symbolic act and transpires within the orbit of a larger whole wherein every contribution is coequal in the history of all works (76). And although Jameson does take Bakhtin to task $(1981,84)$, the two authors agree on Bakhtin's position that a "dialogue of languages is a dialogue of social forces perceived not only in their static co-existence, but also as a dialogue of different times, epochs and days, a dialogue that is forever dying, living, being reborn" (Jameson 1981, 365). The concept of the text as a closed document is thus anathema both to Jameson and to Bakhtin.

8 On "isms" appearing during Debussy's lifetime, see Watkins (1994). To some it may seem odd that Rossetti is cited here, given his dates, and yet the pre-Raphaelite movement itself had far-reaching consequences in France, and was to play out in such Debussy works as "De rêve," from Proses lyriques (1892-95), Trois chansons de France (1904), and Pelléas. 
own horizon within someone else's horizon. There takes place within the novel an ideological translation of another's language, and an overcoming of its otherness-an otherness that is only contingent, external, illusory. Characteristic ... is a positively weighted modernizing, an erasing of temporal boundaries, the recognition of an eternal present in the past. (Bakhtin 1981, 365-66)

Bakhtin applies the concept of heteroglossia extensively to the approaches to the novel taken by Dickens and Dostoevsky, among others. His theories, however, are applicable well beyond the world of the nineteenth and early twentieth centuries. ${ }^{9}$ Heteroglossia, for instance, allows for multivalent connections to be drawn between works such as John Barth's Giles: Goat-Boy (1966) and Tom Robbins's Jitterbug Perfume (1984). In modernizing Classical mythology, both of these later twentieth-century American novelists erase temporal boundaries by treating the escapades of a present-day horned god-a Pan or some other satyr. Barth comes to know his own voice in overcoming the otherness of the mythological figure and in the process endorses T.S. Eliot's theory that an author must not only tap into the pastness of the past, but also into its presence. In a like way, Robbins comes to establish his own horizons in part through those of Barth. ${ }^{10}$

For Bakhtin, all precursors have critical roles to play, no matter how elusive, in the work of an author. Indeed, Bakhtin, writing in "The Problem of Speech Genres" (1986, 68-69), adds a third party to the dialogue between author and precursor, namely the interpreter, who must recognize and respond to the interplay of numerous texts. In the final analysis, as Bakhtin puts it, "any utterance is a link in a very complexly organized chain of other utterances." The speaker, like the author, "does not expect passive understanding that...only duplicates his own idea in someone else's mind." Lines of communication between the past, present, and future-between precursor, author, and interpreter-are kept alive in perpetuity. The result is a complex dialogue wherein the active "listener becomes [another] speaker." 11 Thus the present in the guise of the listener is folded into acts of speech from the past. And so too the present in the guise of the interpreter is folded into extant acts of writing.

\section{"GolliwogG's CAKe-WALK"}

There are many passages in Debussy where the language and contextual horizon of one composer is overcome by the language and horizon of a later composer-

9 Bahktin frequently extends his own horizons into antiquity. See Branham (2002).

10 The reference to T.S. Eliot appears in Tatham (1971,67-68). While Robbins does not cite Barth directly, each writer (as Reising [2001, 465] claims of Robbins) "engages us where it might be said to count, by provoking his readers to consider possibilities outside of ... conventional frames of reference, challenging us to interface with paradox and mystery."

11 A notable parallel exists, then, between the role Bakhtin ascribes to the interpreter and what amounts to a fundamental tenet of Symbolism, a movement with which Debussy (to 1900, at least) was intimately associated. In the Symbolism of Baudelaire, Mallarmé, and others, no work is deemed complete in and of itself. Rather, the very act of completion rests with the interpreter's communion with the internal mystery of the work. See Ward and Patty (2001). The responsibility of the interpreter became increasingly significant as Symbolism gave over to Orphism, Surrealism, and Dadism. 

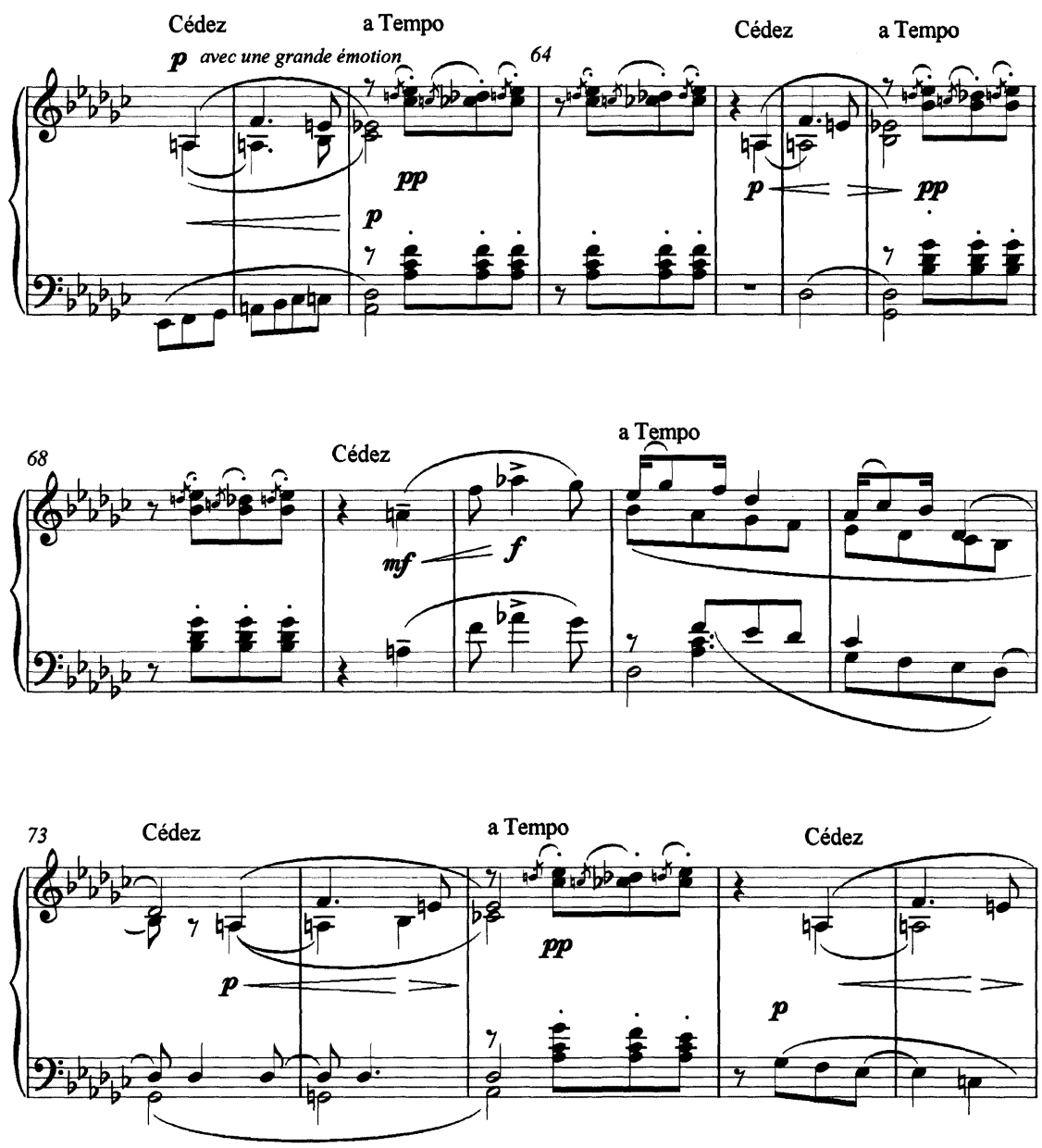

Example 1. “Golliwogg's Cake-Walk," Trio, bars 62-77

where an "otherness" in the Bakhtinian sense is translated and modernized. Roy Howat, for instance, makes the case for a direct association between bars 3-4 of the "Toccata" from Debussy's Pour le Piano and bars 3-4 from the "Prelude" in Bach's E major Partita for Violin, BWV 1006 (Howat 1985, xx). And Paul Roberts contextualizes the stylistic divide between Debussy's Pour le Piano of 1901, and his Estampes of 1903 in terms of influence: he contends that the transformation Debussy's style underwent in the later work was a direct response to Ravel's Jeux d'eau (1901) (Roberts 1996, 161). ${ }^{12}$ For the purpose of the present study, however, by other we shall mean Wagner: the otherness of Wagner's music, in the words of Bakhtin, is overcome in Debussy's.

A famous or perhaps infamous reference to Wagner occurs in the Trio section of "Golliwogg's Cake-Walk," the final piece in Children's Corner (see ex. 1). The 

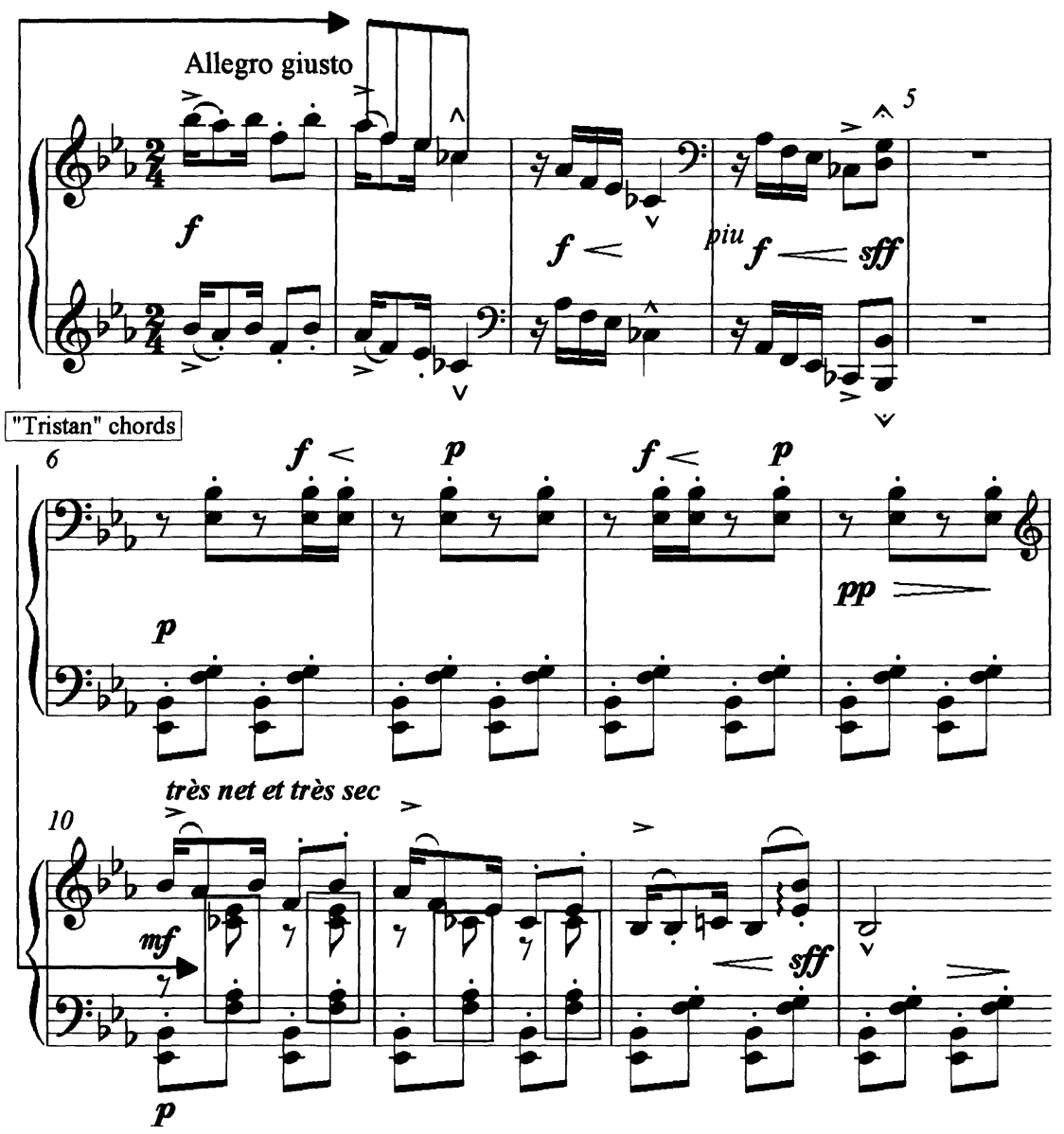

Example 2. Tristan in "Golliwogg's Cake-Walk," bars 1-13

opening gesture of Tristan und Isolde is parodied in the right hand of bars 61-62, the gesture encased within a stylized dance. Debussy appears to be adopting a comedic and satirical tone by juxtaposing allusions to a high operatic genre with the lowly genre of the cakewalk, "avec une grande émotion." Conspicuous in its absence, however, is any clear and uncontested reference to the opera's hallmark sonority, the Tristan chord. Debussy issues a challenge to Wagner, however, by means of an obscured statement of the Tristan chord following the downbeat of bar 63. Coming on the heals of a melodic parody in bars 61-62, the Tristan chord is alluded to by means of an inverted dominant-ninth chord built on D-flat, with the fifth in the bass. A tonicizing I of $\mathrm{G}$ flat (with added sixth) arrives in bar 67, a thoroughly banal solution to the essential tonicizing ambiguity of the Tristan chord in Wagner's hands. The ideological translation of Wagner here is at least threefold: (1) high Wagnerian opera is equated with music-hall entertainment in the guise of the Cake-Walk; (2) the profundity of the Tristan Prelude and its famous signature chord is relegated to the Trio section of a "lowly" dance 
form; and (3) the Tristan chord is deformed via inversion, and assigned to an off-beat accompanimental role. This ideological translation of Wagner is meant to diminish the elevated posture that Wagner so carefully cultivated for himself. Here Wagner's horizon has been subjected to modernization in a manner comparable to what Bakhtin describes as "an erasing of temporal boundaries [and] the recognition of an eternal present in the past."

But the Tristan chord is present elsewhere in the "Golliwogg's Cake-Walk" (see ex. 2). In linear terms, the chord is unfolded continuously in bars 2-4, the Allegro giusto portion of the opening (as A-flat, F, E-flat, C-flat); vertically the chord sounds in the inner voices beginning in bar 10 at "très net et très sec": $: 13$ Net and sec, clear and dry, and yet somewhat shrouded: here Debussy produces an instance of what Bakhtin calls "the process of coming to terms with another's language in one's own."

This ideological translation of Wagner at Debussy's hands necessitates a critical reinterpretation of "Golliwogg's Cake-Walk": the comedic, satirical tone of the Trio vanishes, and in an instant the composition appears before us in a very different light. Following Hayden White and the metalinguistic theory of tropological discourse, I have argued that as a subtext in "Golliwogg's CakeWalk" Wagner is portrayed in tragic terms. ${ }^{14}$ In so doing, Debussy validates a credo central to Harold Bloom's "anxiety of influence": Debussy purposefully misreads Wagner in order to intimate that Wagner did not go far enough in his vision for the Tristan chord and its usage. And by extrapolation, Debussy also intimates that Wagner did not go far in his very outlook on music itself. In spite of the radical potential of the Tristan chord, Wagner's attachment to staid common-practice harmonic progressions in Tristan did not allow him to move beyond the stranglehold of the past. ${ }^{15}$

Consider in this regard Debussy's comments written for Gil Blas in 1903 (five years prior to the composition of Children's Corner). Debussy expounds upon Wagner's legacy, claiming

[Wagner] never did anything of real service to music, and he never did much for Germany either .... . And when Wagner in a stupid outburst said, "And now you have an art," he might just as well have said: "And now I leave you in a vacuum; it's up to you to get out!" (Debussy 1977, 96)

Getting out of a vacuum will prove an apt metaphor in the account that follows. Therein both Wagner and the populated past meet in another composition from Children's Corner-a composition steeped in heteroglossia.

13 To my knowledge, Roy Howat $(1985, \mathrm{xxi})$ was the first to make the connection between the opening of "Golliwogg's Cake-Walk" and Tristan, stating that bars 2-4 and 10-11 "literally and obstinately 'rag' the four notes of the 'Tristan' chord (F, $W, E^{\text {', and }} A^{b}$ )."

14 See Marion 2007. Debussy's strategy, of course, is to stake out his own compositional ground. Ayrey (1994) also explores the application of tropological theory in Debussy.

15 This is not the place to pursue the charge of racism that underpins Debussy's association of Wagner and an oppressed people, namely African-American Blacks. Suffice it to say that Debussy's juxtaposition of high and low art forms has a caustic tone to it. On Wagner's harmony, see the pioneering work of Robert Bailey (1985) and in particular his formalization of the "double-tonic complex" in Tristan and other Wagner compositions. 


\section{"SERENADE FOR THE DOLL"}

With "Serenade for the Doll" (the collection's third piece) Debussy opens the lines of communication between past and future by means of both a backward and a forward orientation toward tonality. ${ }^{16}$ Compositional levels in "Serenade for the Doll" are organized according to radically different principles, implying multiple horizons in the guise of text and subtext as well as figure and ground. The familiar dominant and tonic polarity of common-practice tonality operates here. But so does a generative principle antithetical to common-practice tonality-motion along a circumscribed string of perfect fourths. The latter represents a direct move into a future of Debussy's own making. It is Debussy's response to a Wagnerian past, however, that fuses-as heteroglossia-the two orientations.

The refrain-like structure of "Serenade for the Doll" suggests a Rondo design: A1, bars 1-13; B1, bars 14-29; A2, bars 30-42; B2, bars 43-52; C, bars 53-83; A3 and Coda, bars 84-124. Section A1 (bars 1-13) is reproduced as ex. 3.
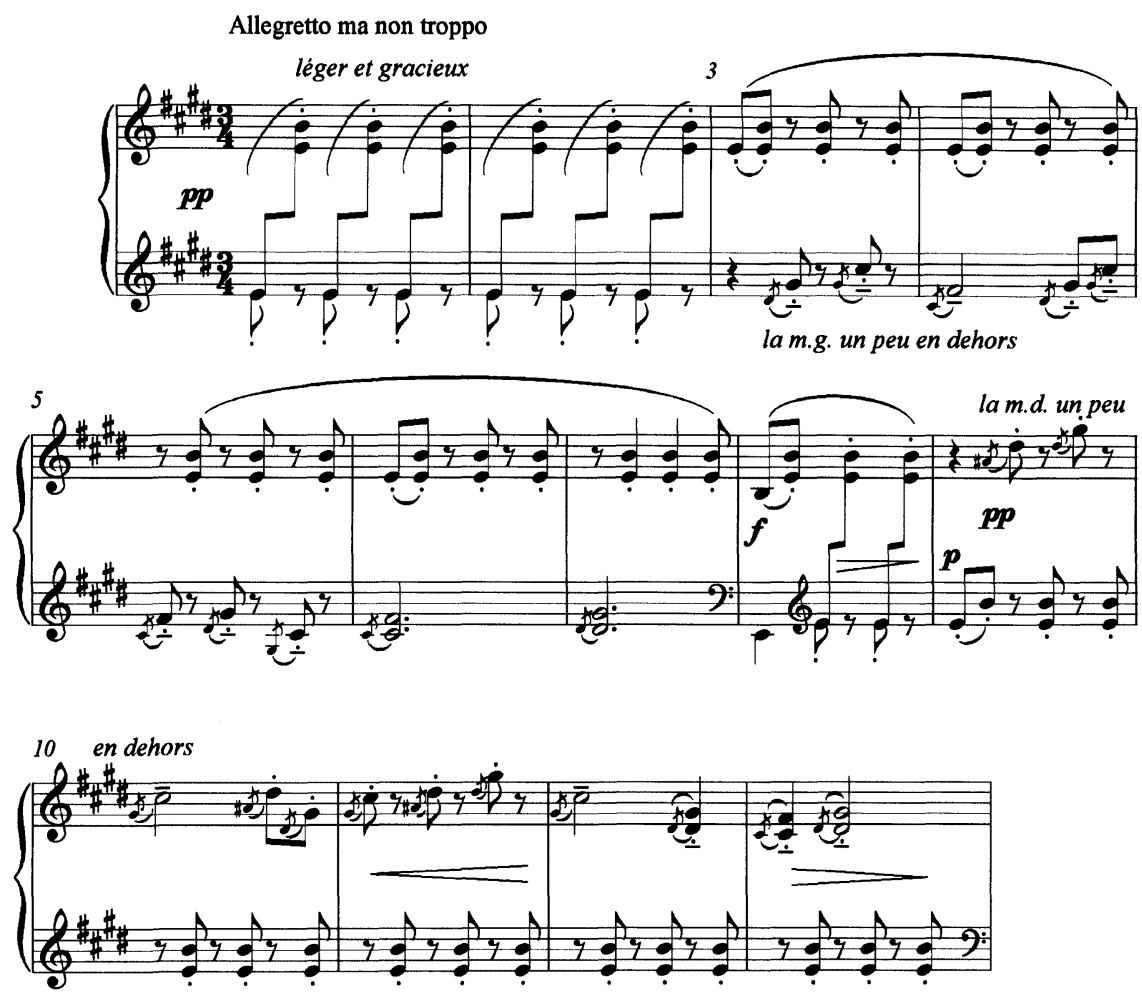

Example 3. "Serenade for the Doll," section A1, bars 1-13

16 Grappling with past and future simultaneously, Debussy renders provisional any sense of boundary between historical periods. He does so as a means of promoting an eternal present. This provisional gesture itself represents nothing short of a marker of the times. Greene (1982) holds that such markers are always tangible and era specific. 
Disparate events coexist from the outset of the piece. The perfect fifth $\mathrm{E}$ to B (initially representing a two-bars introduction) serves as a drone-like accompaniment from bar 3 onward. Juxtaposed against it in bars 3-7, a string of perfect fourths stands as a melody. This quartal melody is represented as two related pitch collections in ex. $4 a$

(a)

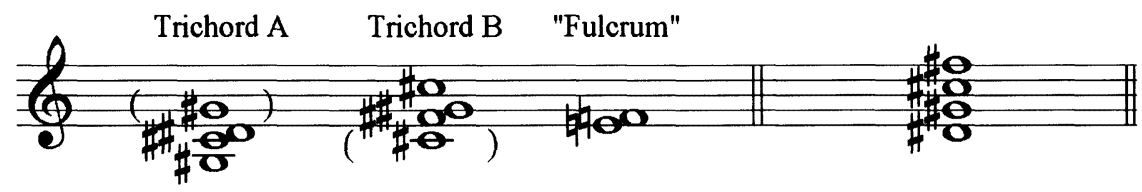

Example 4. "Serenade for the Doll," interpreting the melody, bars 3-7

The example projects a mirror symmetrical image between the two pitch tetrachords. Tetrachord A comprises the accaciaturas in the left hand of bars 3-7 (G\#3, C\#4, D\#4 and G\#4). Tetrachord B comprises the pitches of the tones to which the accaciaturas are attached (C\#4, F\#4, GH4, C\#5). Each tetrachord contains within itself two symmetrical trichords. The tetrachords, as noted, are related symmetrically to each other. The axis by which one transforms to the other is the dyad E and F. ${ }^{17}$ As we shall see, this particular dyad is of some consequence in "Serenade for the Doll." 18

In ex. $4 b$, the four pitch classes used in the left hand are represented as the pitch collection $D \#-G 甘-C \#-F \#$, as a string of perfect fourth intervals. ${ }^{19} \mathrm{~A}$ string of perfect fourths (or variants thereof) might have held sway in a number of syntactical contexts explored by Debussy at the time of the work's compositioncontexts based upon tonal, pentatonic, and set class $(0,2,4,7)$ collections, for example. But the events of "Serenade for the Doll" emphasize a syntax of perfect fourths, an emphasis that remains unchallenged as the piece progresses. The melody in bars 9-13, for instance (in a higher register than that of bars 3-7 and presented in the right hand rather than the left), is predicated upon a string of perfect fourths $A \sharp-D \sharp-G \sharp-C \# .20$

The whole of section Al comes into sharp focus when explored from the perspective of perfect fourths. The perfect fifth $\mathrm{E}$ to $\mathrm{B}$ of the accompaniment from the head of the movement serves as anchor for a five-note string of perfect

17 In using the term transforms, I allude to the work of David Lewin (1987), Richard Cohn (1997), and a growing list of practitioners in what is becoming reified as neo-Riemanian transformational theory. Traditional operations mapping G\#3, CH4, and D\#4 (trichord A) onto FH4, GH4, C\#5 (trichord B) include I9A $\rightarrow B$ and T5A $\rightarrow$ B. Parks 1989 widely explores the application of set-class theory in Debussy's œuvre.

18 The dyad might even be equated with what McCreless (1991), in other contexts, identifies as a signature event impacting upon aspects of complete pieces.

19 Robert Moevs (1969) promoted the concept that variously sized intervallic cells assume heightened roles in Debussy music. See, too, Parks (1989) and Karpinsky (1991).

20 I treat these strings of ascending perfect fourths independent of harmonic function so as to highlight the coexistence of the two stratagems. Elsewhere (Marion 2001) I promote the concept that several independent storylines are manifest at different layers of a Debussy composition-some of which have very little to do with one another. Bakhtin's heteroglossia aligns well with such a concept. 
fourths unfolded over the course of bars $1-13, A \#-D \#-G \#-C \#-F \#$. It is tempting to account for this string in terms of pentatonicism, as the pentatonic collection F\# G\# A\# C\# D\#. But if this string of perfect fourths is merged with the accompanimental $E$ and $B$ (as the perfect fourth $B$ to $E$ ), the string is extended by two steps to set all the pitches of section $A 1$ into one large background perspective. In other words, the complete pitch-class content of bars $1-13$ is equivalent to a seven-note string of fourths (from A to E, see ex. 5). ${ }^{21}$

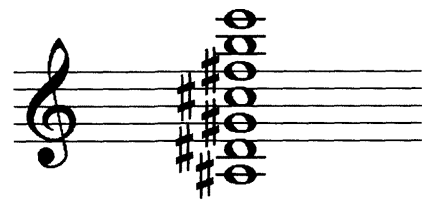

Example 5. "Serenade for the Doll," pitch-class content, bars 1-13

The attention given here to the perfect fourth string should not overshadow the guiding role that common-practice tonality retains in the composition, for "Serenade for the Doll"-published in 1908-ends squarely in E major. What is more, E major is established and confirmed in ways that embrace the common-practice tradition more and more directly as the piece continues to unfold. Perfect fourth strings, in other words, contest with common practice tonality in a dialogic fashion, one that Bakhtin might have found noteworthy.

The tonal overview of bars 1-51 sketched in ex. 6 shows how the underlying functional harmonic structure and the string of fourths are conjoined for nearly half the piece.

\section{FORMAL SECTIONS:}

A1 B

A2

B2

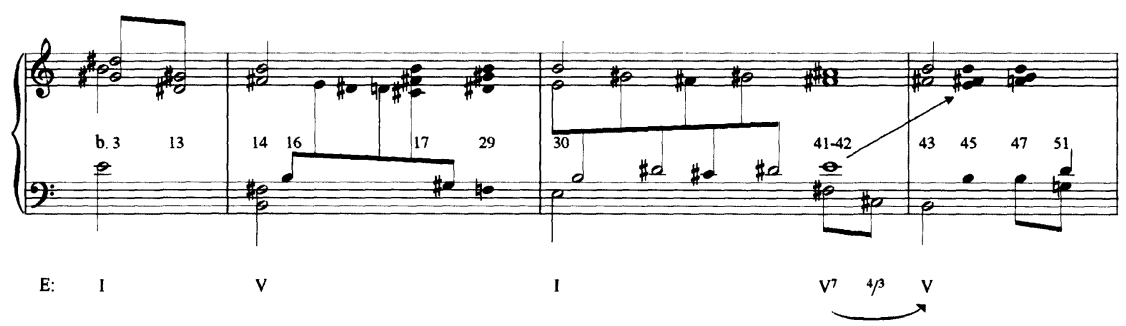

Example 6. "Serenade for the Doll," tonal overview, bars 1-51-the old and the new

As heteroglossia, terms representing the "old" and the "new" come together, thus erasing temporal boundaries as Debussy captures the eternal present of the past. The old common-practice harmonic structure (predicated upon alternating motion between tonic and dominant sonorities in $\mathrm{E}$ major) is largely provi-

21 The collection of pitches in ex. 5 comprise what in other contexts are defined as the B major scale and the E Lydian mode. 
sional until the arrival in bar 41 of a fully-developed dominant seventh of B-V7 of $\mathrm{V}$ in the home key.

The juxtaposition of these two organizing stratagems, old tonal and new quartal organizational events, is brought about in careful ways. Prior to bar 41, the authority of functional tonality is blurred, notably by omission of chordal thirds at critical points of arrival. For instance (see ex. 6), in bar 14 the B sonority is missing the triadic third DH, and similarly in bar 30 the E sonority is missing the triadic third $G$. The omission of these notes underscores a figure and ground relationship that obtains here between novel melodies built from interval strings and traditional chordal harmony.

The divide between eras continues. The beautiful expansion of $V$ of $B$ in bars 41-42 is predicated upon the leap of a fourth from chordal root $F$ fifth $C \#$ in the bass, a vivid reminder of the heightened role afforded motion by perfect fourth in the piece. Metaphorically, two worldviews, the old (represented by tertian sonorities, perfect fifths, and dominant-to-tonic motion) and the new (expressed in the form of recurring reference to strings of perfect fourths) exist simultaneously in "Serenade for the Doll." This is a Bakhtinian merger of historical boundaries: the multiple voices present in Debussy's piano piece resonate collectively.

The sonority heard in bar 29 (see ex. 6) brings back a central figure in Debussy's incarnation of heteroglossia. After 1865, the use of a half-diminished seventh like that of bar 29 alludes to the Tristan chord and is provocative. ${ }^{22}$ The chord's vertical constitution and its linear continuation are red-letter entries for telling the tale of "Serenade for the Doll," a tale in which Tristan looms large. ${ }^{23}$ The Rubicon has been crossed, and now begins an account of the war Debussy waged against Wagner.

Three forms of the Tristan chord together with their continuation into dominant-seventh sonorities are provided in ex. 7 in order of appearance in the opera's Prelude. They are labeled "Tristan 1," "Tristan 2," and "Tristan 3," respectively. Not one of the dominant chords (E7, G7, or B7 respectively) proceeds directly to its tonic. This lack of resolution contributes to the sense of timelessness that serves as a central theme in the opera. ${ }^{24}$

Addressing ex. 4, I suggested that the dyad $\mathrm{E}$ to $\mathrm{F}$ constitutes a fulcrum around which two tetrachords relate (compare ex. 8a). Example $8 \mathrm{~b}$ focuses on what I shall call the principal aural event of bars 1-13, which is made concrete in bar 30. The sonority is sensitive to the world of perfect fifths and tertian sonor-

22 The sonority has, of course, been widely discussed since its initial Wagnerian usage-Ernst Kurth (1968, originally published in 1923) and Alfred Lorenz (1926) being among the first to do so. Rothgeb (1995) explores the Tristan chord from the standpoint of nomenclature and historical precedent, and takes issue with global classifications of the event as a functional half-diminished seventh chord.

23 The argument for Tristan's impact upon "Serenade for the Doll," of course, is brought into sharper focus by association with its companion piece, "Golliwogg's Cake-Walk," which engages so directly with the Wagner work.

24 As mentioned above, Bailey (1985) coins the term double-tonic complex as a means of accounting for the friction between the principal tonal regions in the opera's Prelude, and more widely in much of Wagner's music. It must be stated that issues of temporality and temporal flow in Wagner are anything but simple to unravel, as Adorno (1973) attests. 

(a) "Tristan 1"
(b) "Tristan 2"
(c) "Tristan 3"

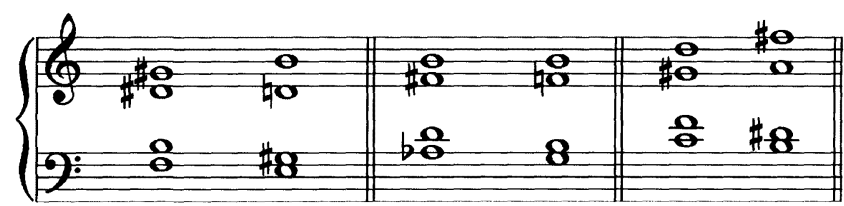

Example 7. Tristan Chords

ities: it stands as a tonic chord with added seventh in the key of E. But it relates as well to the world of perfect fourth strings, the upper dyad being a component of the string of fourths operative over bars 1-13. Examples $8 \mathrm{c}$ and $8 \mathrm{~d}$ reveal an important relationship to the Tristan chord.

In Example 8c, the bass moves from $\mathrm{E}$ to $\mathrm{F}$ : the perfect fifth $\mathrm{E}$ to $\mathrm{B}$ becomes a

$\begin{array}{lll}\text { (a) "Serenade" } & \text { b. } 3 \text { - } 7\end{array}$

(b) b. $1-13$

(c) "Tristan 1"

(d) its Wagnerian "resolution"

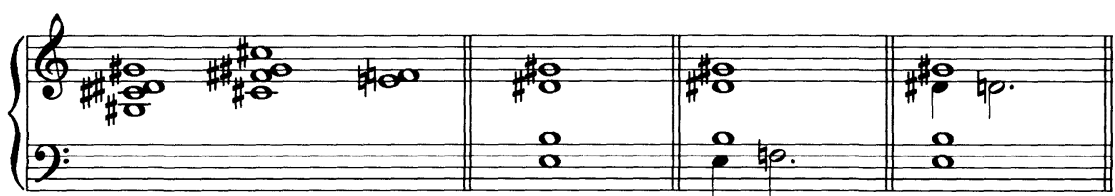

Example 8. Pitch material of bars 3-7 and the focal dyad

tritone, but the perfect fourth dyad $D \# G \#$ is preserved. The projection of the tritone here is anything but capricious: the $\mathrm{E}$ and $\mathrm{F}$ axial dyad was introduced earlier in conceptual terms, but it returns here in realized form. The new harmony replicates "Tristan 1" and the chord encountered at the conclusion of section B1 in bar 29, beat 3 (exs. 9a and 9b). In ex. 8d, E natural remains unaltered, but $D \#$ is taken to D natural. The perfect fourth is converted thus into a tritone, and being so converted it replicates the dominant seventh sonority toward which "Tristan 1 " is directed. Said in another way, over the course of bars 3-30, Debussy creates an allusion to Wagner's elaborate voice leading from the Prelude to Tristan, albeit by reducing Wagner's efforts to a mere neighbouring gesture: the semitonal slide from $\mathrm{E}$ to $\mathrm{F}$ and back to $\mathrm{E}$.

Tristan has been conjured: sonorities from "Serenade for the Doll" allude to the celebrated sonority from the opera and to its continuation to a dominant seventh chord. Debussy, however, is not finished his critical refiguring of the source composition. Where Wagner was arguably content to assign a pre-dominant function to each of the three Tristan sonorities in the service of "endless melody," Debussy leads "Tristan 1" in a rather different direction, as shown in ex. 9.

The reduction provided in Example 9b shows "Tristan 1" at work in bars 26-29, and its continuation into bar 30 where the opening of "Serenade for the Doll" returns with variation. In Debussy's world, "Tristan 1" represents the voice-leading preparation for the tonic sonority of bar 30 , and not a Wagnerian 

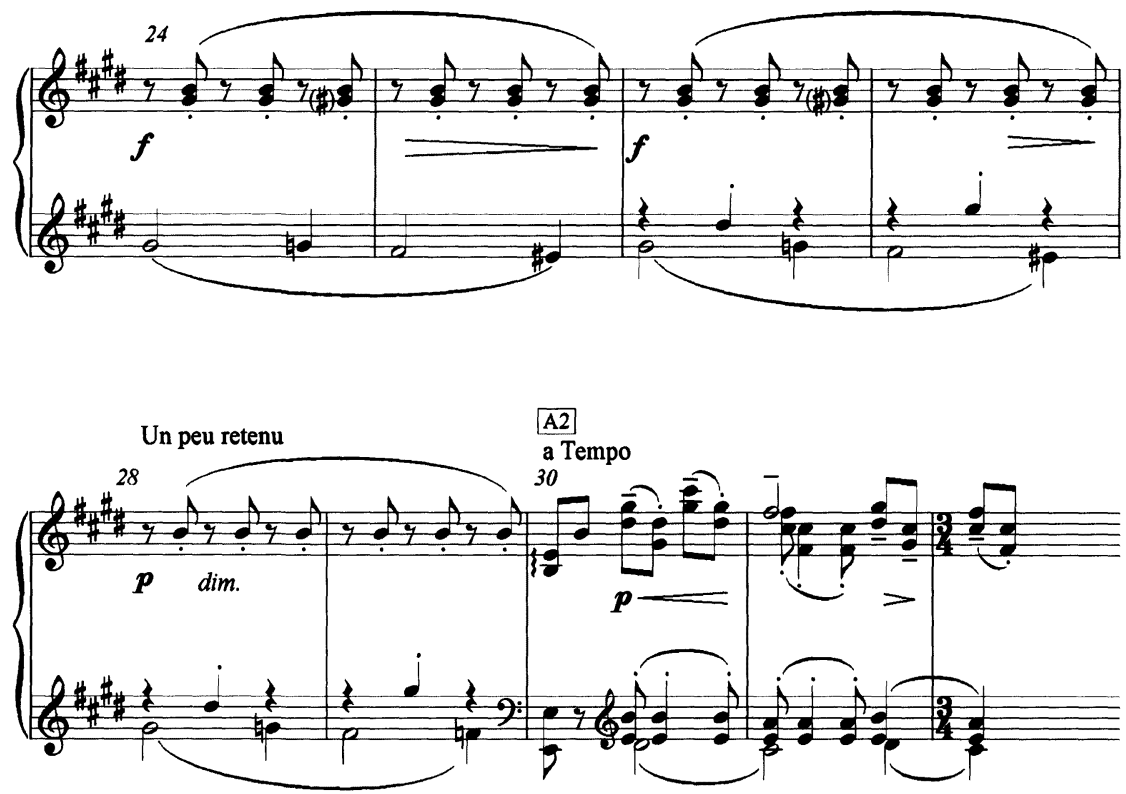

Example 9a. "Serenade for the Doll," bars 24-32

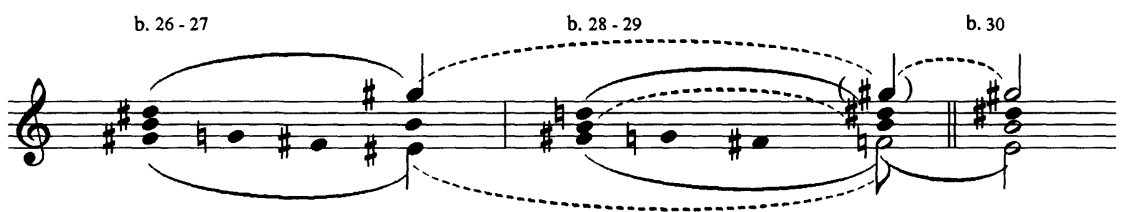

Example 9b. "Reduction"

pre-dominant chord. (The voice leading from bar 28 to bar 30 reverses the semitone slides summarized in Examples $8 \mathrm{c}$ and $8 \mathrm{~d}$ : $\mathrm{F}$ moves to $\mathrm{E}$, while $\mathrm{D}$ proceeds to $D$-the latter move wresting from $D$ any functional affiliation as chordal seventh.)

Some of Debussy's allusions to the Wagnerian past are particularly subtle. The dominant of $B$ (V7 of $V$ with respect to $E$ major) is unfolded elaborately in bars 39-42, just in advance of section B2 of the Rondo design (see ex. 10). The chordal seventh-E natural of the alto voice (first sounded in bar 39)-does not resolve, however, in an expected manner (to $\left.D_{H}\right)$. Instead, $E$ is suspended at the outset of Section B2 (bars 43-46) as a dissonant fourth above the new bass, and eventually rises to $\mathrm{F}$ in bar 47 , where it again stands as dissonant chordal seventh, this time the seventh of the evolving $G$ major-minor sonority (ex. 10b). ${ }^{25}$

25 As mentioned, no chordal third appears in bars 43-44. Thus E4 is the "lingering" aural innervoice pitch of reference in these bars (given its pronounced role in bars 39-42). E4 sounds again in the tenor voice in bars 45-46 above the pitch B3 (as in bars 39-42) and slides up to F4 in bar 47 and following. F4 sounds again in the alto voice in bar 52 (see ex. 10a). 

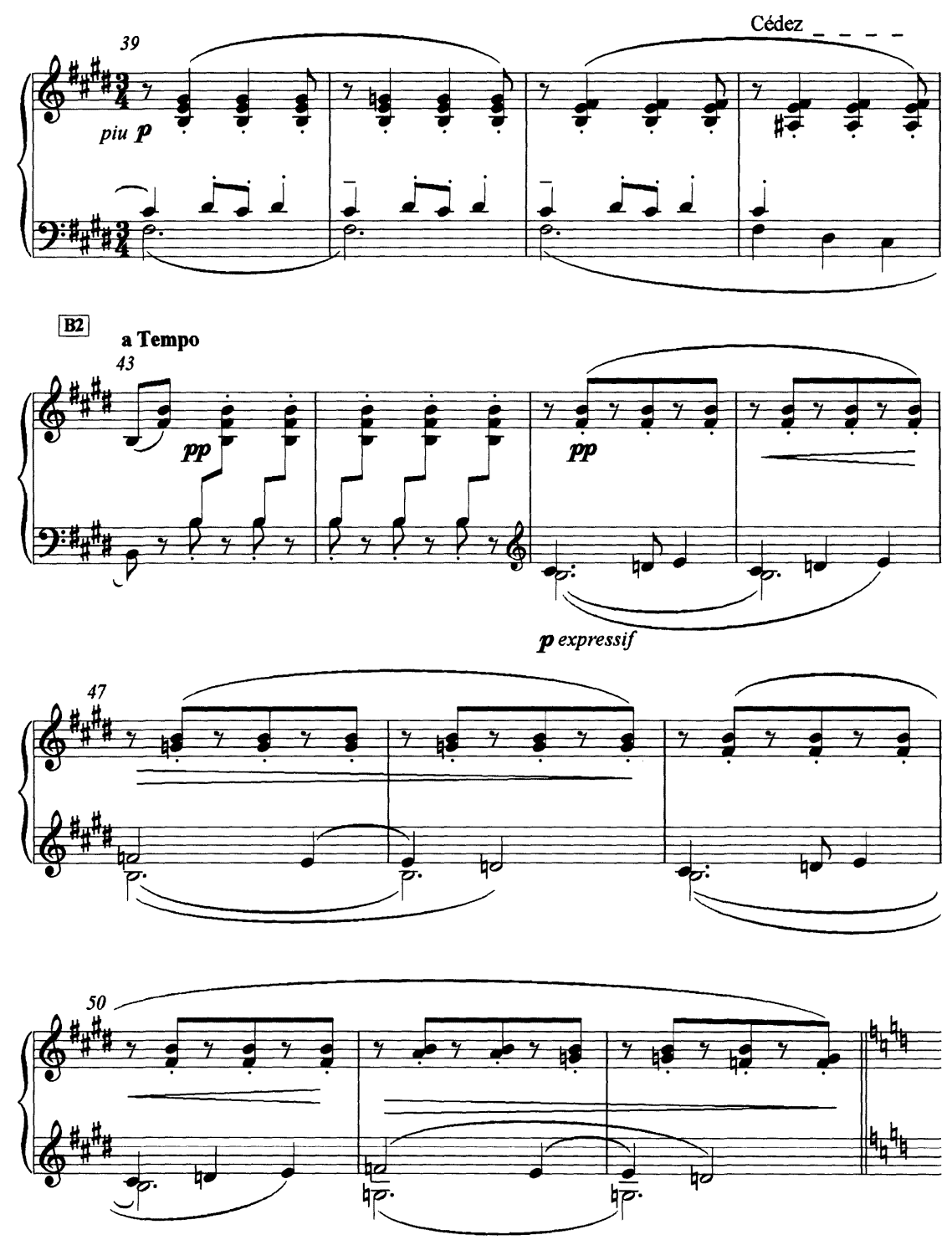

Example 10a. "Serenade for the Doll," bars 39-52

The semitone shift from $E$ to $F$ over the course of bars $39-51$ is another manifestation of the focal dyad in "Serenade for the Doll" (as first mentioned in the context of bars 1-13). The shift makes a cross-reference: the arrival of G7 in "Serenade for the Doll" (in bar 47) calls to mind the continuation of "Tristan 2" to G7 in Tristan's Prelude (see ex. 7). The prolongation of G7 in bars 47-52 of "Serenade for the Doll" thus delays the arrival of the anticipated dominant of $\mathrm{E}$, the home key. As well, the slow emergence of Debussy's G7 is achieved largely in the left hand of bars 45-52. The right-hand in these bars, however, prolongs the 


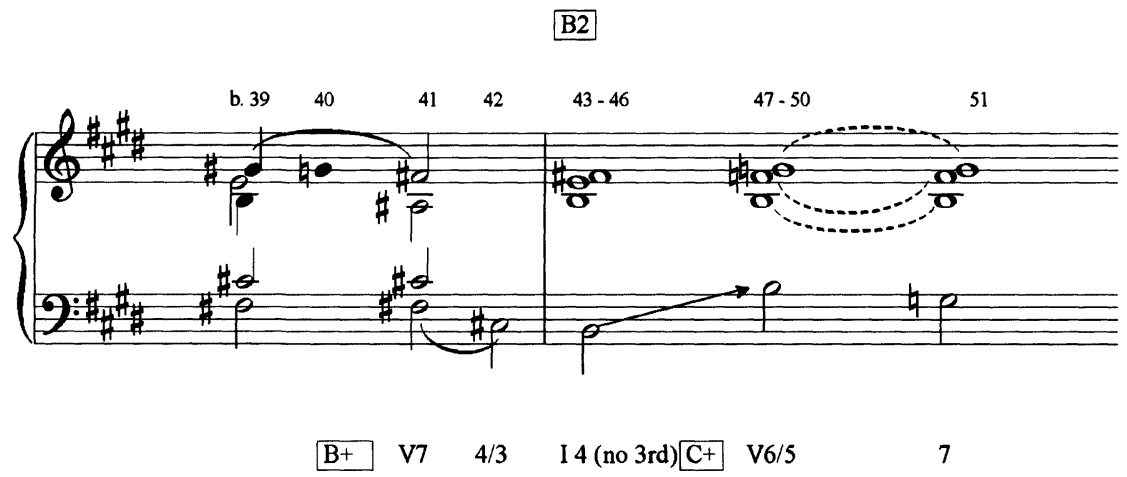

Example 10b. "Reduction"

perfect fourth $F \#-B$, the upper dyad of Wagner's "Tristan 2 "-a chord similarly directed to V7 of C. As a result, events associated with "Tristan 3" and with the tonic key are kept from entering too early. ${ }^{26}$

To this point in the article, I have shown how the principal verticality of "Serenade for the Doll" refers to "Tristan 1" and thus to its continuation to a dominant seventh chord on E. The terminal point of "Tristan 2"-a G majorminor seventh chord-also features prominently in "Serenade for the Doll."27 Allusion to "Tristan 3," then, would complete this Wagnerian association, and that is just what Debussy makes in the approach to the climactic gesture of the piece (see ex. 11).

Bars 82-83, the final bars of section $C$, mark the return of the dominant of $B$, the chord encountered initially at the close of A2 in bars 39-42. In bars 82-83, Debussy seems intent again on denying the chord its customary resolution in common-practice terms. Bar 84 ushers in a radically-altered version of the Rondo refrain (section A3), initially against the backdrop of a minor-minor seventh chord in $4 / 2$ position, E F A CH, in lieu of the anticipated tonic of the key of B. Bars 84-89 are a parenthetical interpolation-an interruption-prolonging the dominant of $B$. The dominant of $B$ is reestablished in bars $90-91$ and then progresses (as a dominant-ninth chord) at last to the dominant of $\mathrm{E}$ in bars 92-93 (albeit minus its third in bar 93, D ambiguity). Implicit here is reference to "Tristan 3," which likewise is oriented to the dominant of $\mathrm{E}^{28}$

26 In other words, the passage encountered in ex. 10a could have been written with B7 (as goal) arriving in bar 47 . The path Debussy forges, however, veers off in another direction precisely where B7 is expected to enter.

27 In a peculiar sense, the fact that G7 in "Serenade for the Doll" is not harmonically functional, helps to align it with the initial G7 sonority of Wagner's Prelude, for neither event proceeds directly to a tonic I in C. Debussy's restricted use of "Tristan 2" (employing only two elements of that sonority, FH-B) has a decidedly Bakhtinian flair: it is synecdoche (i.e. reduction, both in terms of the Wagnerian event, and of the prevalent string of fourths in Section Al of his own piece). Refer to ex. 5 and to ex. 7.

28 It is notable that Wagner breaks the sequence initiated at the outset of the opera's Prelude precisely with the arrival of the dominant of $\mathrm{E}$, and thereafter leads to an $\mathrm{F}$ major chord that is at once affili- 

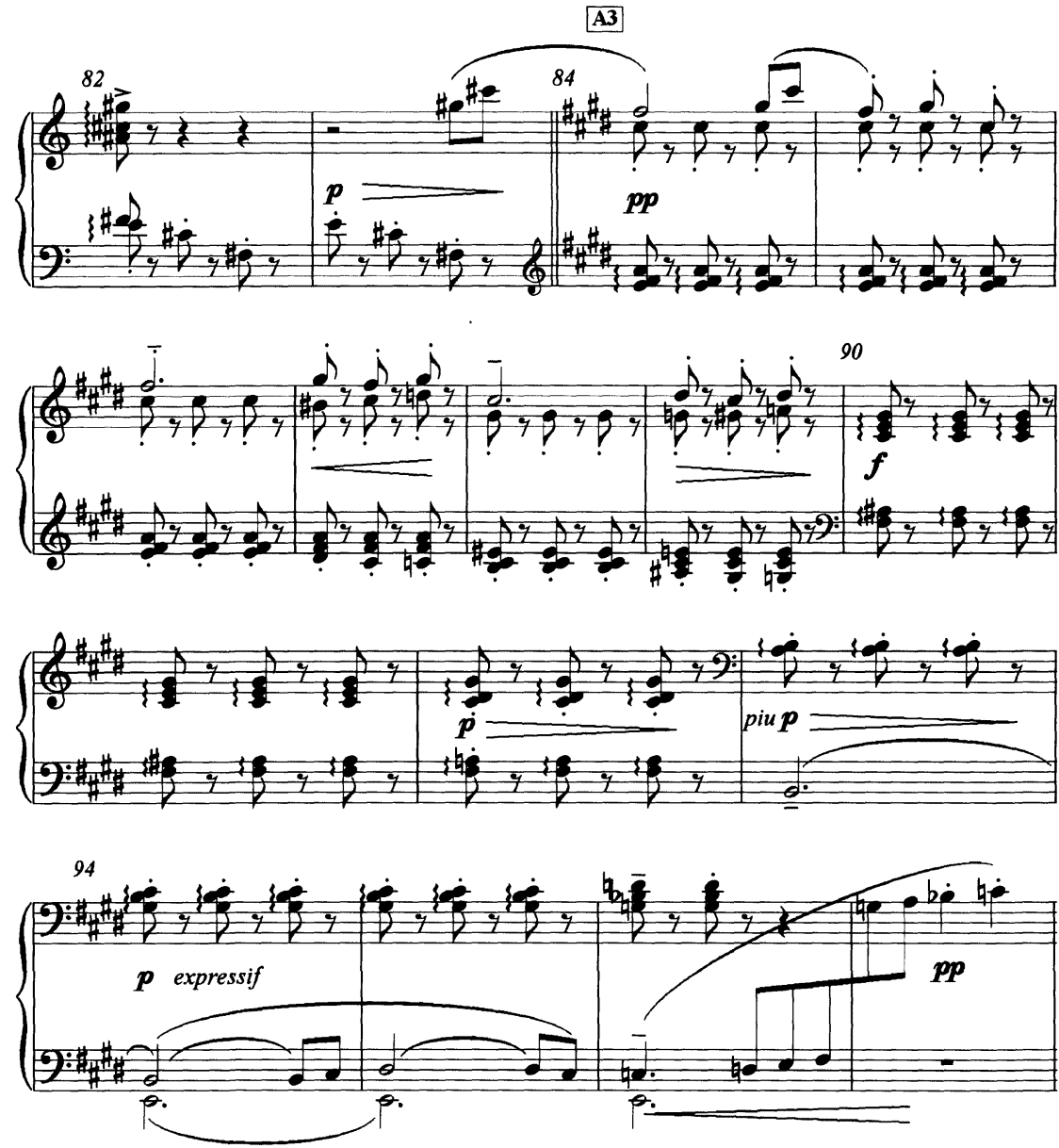

Example 11. "Serenade for the Doll," bars 82-97

The suggestion of a parenthetical interpolation, however, must be explored further. Bars 53-83, section C of the Rondo design, can be regarded as an interruption that spans nearly one quarter the length of the piece. It resembles a fantasy wherein Debussy comes to know vividly his own language through the language of Wagner.

The section is divided into two segments. The first (bars 53-65) takes over seamlessly from section $\mathrm{B} 2$ by retaining the right-hand tones $\mathrm{F}$ and $\mathrm{G}$ heard at the conclusion of bar 52 . This dyad is instantly recontextualized. In bar 53 it is stripped of its association with dominant harmony-no longer standing as the seventh and root of V7 in C. Instead, in the opening bars of section C all four voices orient by stepwise motion toward the A7 sonority that enters in bar 56. A four-bar sequence follows, leading to the $C 7$ sonority of bar 60 (see ex. 12).

ated with $\mathrm{A}$ (as flat-submediant) and C (as subdominant), the two pole tonalities of Bailey's "double-tonic complex." 

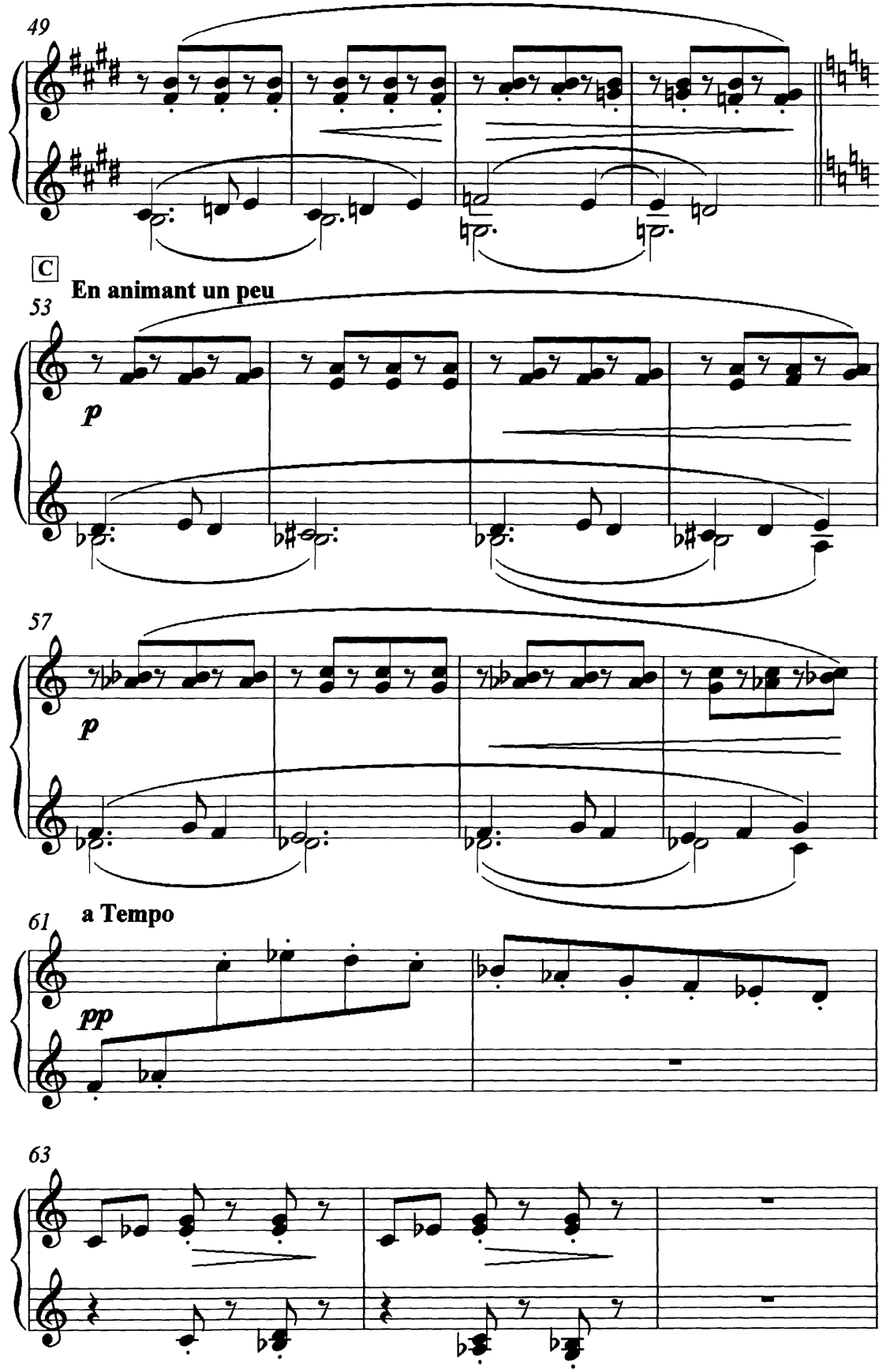

Example 12. "Serenade for the Doll," bars 49-65 
In bars 53-60, the historical barrier between Debussy and Wagner collapses in several ways, not merely by means of the sequence just described-to A7 then C7-which recalls the minor-third relationship in the opening of the Tristan Prelude (consider the relationship of "Tristan 1" to "Tristan 2" in ex. 7). ${ }^{29}$ The sequence ends abruptly in bar 61 , where an $\mathrm{F}$ minor-minor seventh sonority resolves the dominant harmony heard in bar 60 . Tonic and dominant polarities lapse at this point, however: the $\mathrm{F}$ minor-minor seventh yields to a $\mathrm{C}$ minor chord in bar 63 and to a $\mathrm{G}$ minor chord with added sixth in bar $64 .{ }^{30}$ The bass line linking the three sonorities-F to $\mathrm{C}$ to $\mathrm{G}$-unfolds by descending fourths, and as such reconnects with the privileged role accorded strings of fourths elsewhere in the piece. ${ }^{31}$ And as if to underscore this point, Debussy inserts a bar and a half of silent reflection-the longest moment of silence in "Serenade for the Doll"between the $\mathrm{G}$ minor chord and the start of segment two of section $\mathrm{C}$.

If the left and right hands in bars 66-72 are considered separately (see ex. 13), the left hand constitutes a pedal dyad $\mathrm{A}^{b}$ and $\mathrm{B}^{b}$, over which two half-diminished seventh chords alternate: $\mathrm{C} \mathrm{E}^{b} \mathrm{G}^{b}$ and $\mathrm{B}^{b}$, and $\mathrm{D} \mathrm{F} \mathrm{A}^{b}$ and $\mathrm{C}$. The second of these chords, accentuated by a crescendo, sforzando, and roll in bar 72, is the equivalent of "Tristan 3," respelled and rescored. But this allusion is by no means unequivocal: when the two half-diminished chords of bars 69-72 are each combined with $A^{b}$ and $B^{b}$ of the left hand, two contesting dominant ninth chords are produced: $A^{b} C E^{b} G^{b} B^{b}$ and $B^{b} D F A^{b} C$ (with $A^{b}$ in the bass). Bars 69-72 are sequenced at a major second in bars 73-76. The sequence preserves the allusion to "Tristan 3," but juxtaposes against it a new half-diminished seventh chord $\mathrm{E}$ $\mathrm{G} \mathrm{B}^{b} \mathrm{D}$. The sequence also produces another pair of contesting dominant seventh chords over $\mathrm{B}^{b}$ and $C$ of the left hand: $\mathrm{B}^{b} \mathrm{D} F \mathrm{~A}^{b} \mathrm{C}$ (as before, the root $\mathrm{B}^{b}$ is added to the respelled "Tristan 3 ") and C E G B D.

The sequence comes apart in bar 77 and again in bar 79, as a clear dominant harmony built on $F \#$ appears in bars 78 and 80 . The arpeggiating bass in bars 78 , and 80-83 emphasizes repeatedly the dominant chord of B (with chordal ninth in the uppermost voice). This is the sonority that concluded section A2 in bars 41-42, now the ultimate gesture of section $C$, the dominant which (frustrated like that of "Tristan 3") leads to the interpolation starting at bar 84.

One last observation will suggest the depth to which Debussy's interaction with Wagner can be traced. The left hand of bar 66 to the downbeat of bar 78 articulates eight pitches, $A^{b} B^{b} C D^{b} E^{b} E F^{\#}$. If we treat $A^{b}$ and $B^{b}$ as bass and tenor and add to them in linear connection $D^{b}$ and $E$ to produce $A^{b}-B^{b}-D^{b}-E$, and do similarly with the remaining tones to produce $\mathrm{B}^{\mathrm{b}}-\mathrm{C}-\mathrm{E}^{b}-\mathrm{F}_{\#}$, then two more half-diminished chordal associations are to be drawn here. At their point of

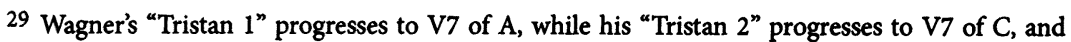
hence the two allude to $A$ and $C$ as tonic harmonies. By adding chordal sevenths to each of the $A$ and $\mathrm{C}$ harmonies in "Serenade for the Doll" (bar 56 and bar 60, respectively), Debussy questions the predominant functionality Wagner establishes for the Tristan chords.

30 Altering Debussy's F minor-minor seventh by semitone ( $C$ to $B$ ) would create the aural equivalent of "Tristan 1." Conversely, altering $E^{b}$ to D would create "Tristan 3." By altering three pitches (while retaining the $A^{b}$ ), the F minor-minor seventh is made to replicate "Tristan $2^{\text {": }}$ F-A $A^{b}$-C-Eb becoming F $\mathrm{A}^{\mathrm{b}-\mathrm{B}-\mathrm{D} \text {. }}$

31 Refer above to the discussion of section Al. 

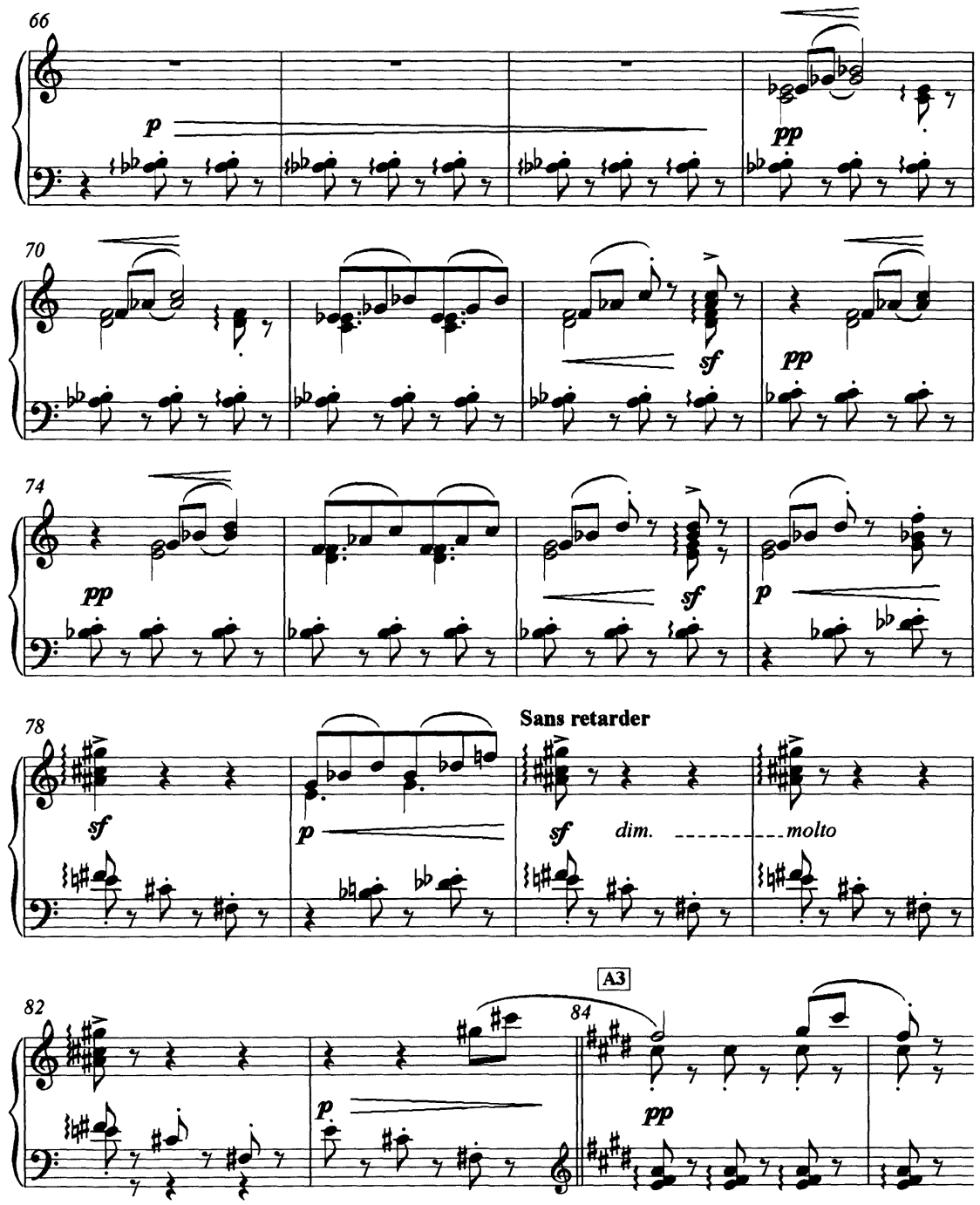

Example 13. "Serenade for the Doll," bars 66-84

culmination in bar 78 (with the arrival of the vertical dyad E FH), however, these linear half-diminished sevenths dissipate, and the dyad itself is contextualized as an element of the rich dominant harmony of B: $E$ as chordal seventh, and $F \#$ as root. 32

32 It will be remembered that section $C$, the fantasy, got underway by converting another seventhand-root pairing, F and G, the uppermost voices in the G7 chord heard at the conclusion of bar 52. 
In ex. 14, I summarize Wagnerian relationships described to date in this article. The upper staff refers to the three harmonies taken from the Tristan Prelude, while the lower staff speaks to Debussy's dialogue with the earlier work. ${ }^{33}$

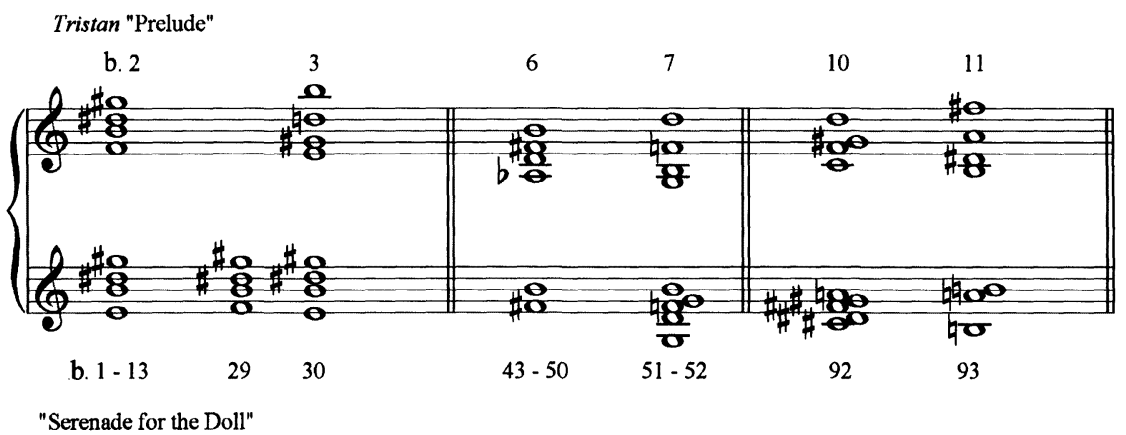

Example 14. Tristan in "Serenade for the Doll," a summary

Comparison is strongest between the two openings (see ex. 14a). As mentioned, Debussy provides only limited aural contact with "Tristan 2," by appropriation of its upper dyad (ex. 14b). Debussy's prolongation of $F_{\#}^{\#}$ and $B$ in bars 43-50, however, leads directly to the G7 chord that enters in bar 51 . The placement of this prolongation between "Tristan 1" and "Tristan 3 " compares with Wagner's positioning of "Tristan 2" and the attendant dominant chord to which it progresses. In the case of "Tristan 3 ," Debussy distorts the source sonority very nearly beyond recognition: save for $G$, each pitch in bar 92 is a semitone higher than its correlate in Wagner; Debussy's chord is presented in a different "inversion" than Wagner's; and finally, Debussy adds a fifth pitch (A) in the place of Wagner's four. But the bar in question follows section C, where Debussy comes to know his own language fully, through the language of Wagner. It is only fitting, then, that the merged horizons associated with "Tristan 3 " are more decidedly Debussyan, than Wagnerian. This act of very nearly voiding the connection between Tristan and "Serenade," however, allows Debussy to till his own soil. The meeting of common-practice and quartally-organized features germinates in the piece and ultimately comes to form a single hybrid. And thus Debussy emerges from the Wagnerian vacuum (see ex. 15).

Following the fourth-laden material of bars 83-84, bracketed in ex. 15a, the dominant of B returns (as V9) in bar 90. Two semitone slides over the course of bars 90-92 facilitate a move into the dominant of $\mathrm{E}$ (fully attained as a dominant thirteenth chord in bar 93) -E natural to D\# in the upper staff of ex.15, and A to A natural in the lower staff. Tonic harmony arrives in bar 94 . The functional tonal sonorities beginning in bar $78-\mathrm{V}$ of $\mathrm{B}, \mathrm{V}$ of $\mathrm{E}$, and $\mathrm{E}$-have been enhanced here by the addition of chordal ninths and thirteenths. The apex of this enhancement procedure occurs in bars 94-95, where six distinct pitches stand

33 The register from the opening of Wagner's opera has been altered in ex. 14. The alteration undermines the crucial role register plays in all music, but it unveils the subtlety of Debussy's allusion to Wagner. 
(a)

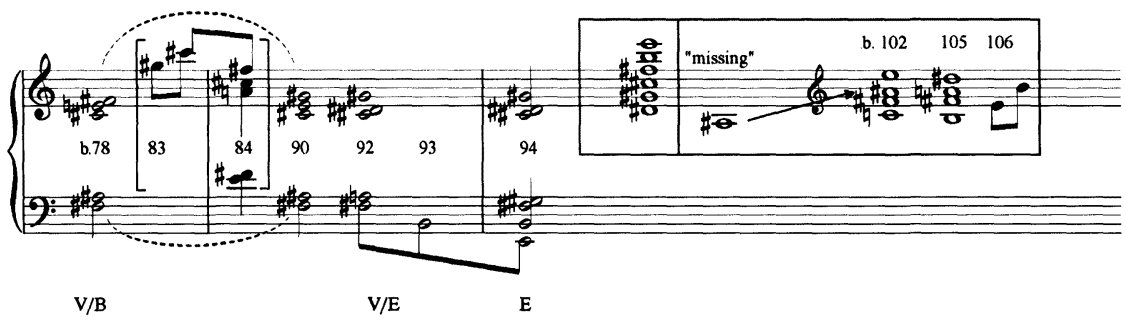

Example 15. "Serenade for the Doll," reduction of bars 78-94

as tonic I of $\mathrm{E}$. The pitch-class content of this last chord comprises all but one element of the complete string of fourths discussed above (see ex. 15b). The missing note, $A$, appears five bars later (in bar 102). There it forms part of a linearly projected augmented-sixth chord in $\mathrm{E}$. That augmented sixth chord progresses to V7 (bar 105), which resolves in turn to I (bar 106).

This last observation can be framed in light of heteroglossia, as one more instance of Debussy overcoming the otherness of Wagner. "Tristan 3" is the least structural of the three Tristan chords in the opera's opening bars, for following its progression to $\mathrm{B} 7$, Wagner breaks radically with the precedents of "Tristan 1 " and "Tristan 2." The earlier chords allude to the principal tonal centers of the Tristan Prelude-A and C, respectively. The B7 sonority does not invoke a third key area, E, to nearly the same extent. In "Serenade for the Doll," however, quite the opposite obtains, for the climax of Debussy's piece turns on setting up B as dominant of $\mathrm{E}$ in a completely functional sense, confirmed in the subsequent resolution to the tonic of $E$ in bar 106.

\section{CONCLUSION}

The old and the new coexist in the works broached in this article, most directly in "Golliwogg's Cake-Walk," but more subtly in "Serenade for the Doll." Reliance on techniques associated with common-practice tonality grounds "Serenade for the Doll": the piece ends in the key of E major. An extended string of perfect fourths, however, accounts for the melodic pitch content met in much of the composition. These observations aside, it is the subtle Wagnerian associations that drive the work and cause it to resonate with Mikhail Bakhtin's concept of heteroglossia: the process of coming to terms with one's own language in the language of another.

In keeping with a wide circle of writers, artists, and intellectuals, Debussy became a musical barometer of the times. He too was seized by the past in a way so characteristic of La belle Epoque, a need to confront the past so as to claim a future of one's own choosing. This future was predicated upon a fusion of historical horizons, a fusion made manifest in the blending of multiple voices, a fusion reflective of the eternal present of the past. 


\section{REFERENCE LIST}

Abbate, Carolyn. 1981. "Tristan in the Composition of Pelléas." 19th-Century Music 5, no. 2: 117-41.

Adorno, Theodor. 1973. Negative Dialectics. Translated by E.B. Ashton. New York: Seabury Press.

Ayrey, Craig. 1994. "Debussy's Significant Connections: Metaphor and Metonymy in Method." In Theory, Analysis and Meaning in Music, ed. A. Pople, 127-51. Cambridge: Cambridge University Press.

Bailey, Robert. 1985. Richard Wagner: Prelude and Transfiguration from Tristan und Isolde. New York: Norton.

Bakhtin, Mikhail. 1981. "Discourse in the Novel." In The Dialogic Imagination: Four Essays, trans. C. Emerson and M. Holquist, ed. M. Holquist, 259-422. Austin: University of Texas Press.

- 1986. "The Problem of Speech Genres." In Speech Genres and Other Late Essays, trans.V. McGee, ed. C. Emerson and M. Holquist, 60-102. Austin: University of Texas Press.

Bloom, Harold. 1973. The Anxiety of Influence. Oxford: Oxford University Press.

- 1975. A Map of Misreading. Oxford: Oxford University Press.

- 1995. The Western Canon: The Books and School of the Ages. New York: Riverhead Books.

Boulez, Pierre. 1991. Stocktakings From an Apprenticeship. Collected and presented by Paule Thévenin. Translated by Stephen Walsh with an introduction by Robert Piencikowski. Oxford: Oxford University Press.

Branham, R. Bracht, ed. 2002. Bakhtin and the Classics (Rethinking Theory). Evanston: Northwestern University Press.

Charle, Christophe. 2001. "Debussy in Fin-de-Siècle Paris." In Debussy and his World, ed. Jane Fulcher, 271-95. Princeton: Princeton University Press.

Cohn, Richard. 1997. "Neo-Riemannian Operations, Parsimonious Trichords, and their Tonnetz Representations." Journal of Music Theory 41:1-66.

Debussy, Claude. 1977. Debussy on Music: The Critical Writings of the Great French Composer Claude Debussy. Selected by François Lesure. Edited and translated by Richard Langham Smith. Ithaca: Cornell University Press.

DeVoto, Mark. 2004. Debussy and the Veil of Tonality: Essays on His Music. Hillsdale, N.Y.: Pendragon Press.

Donnellon, Déirdre. 2003. "Debussy as Musician and Critic." In The Cambridge Companion to Debussy, ed. S. Trezise, 43-58. Cambridge: Cambridge University Press.

Fulcher, Jane. 2001. "Speaking the Truth to Power: The Dialogic Element in Debussy's Wartime Compositions." In Debussy and his World, ed. Jane Fulcher, 203-232. Princeton: Princeton University Press.

Galison, Peter. 2003. Einstein's Clocks, Poincarés Maps: Empires of Time. New York: Norton.

Greene, David. 1982. Temporal Processes in Beethoven's Music. New York: Gordon and Breach Science Publishers.

Holloway, Robin. 1979. Debussy and Wagner. London: Eulenberg Books. 
Howat, Roy. 1985. "Forward." In Oeuvre Complètes de Claude Debussy, ser. 1, vol. 2, ed. F. Lesure, xvii-xxi. Paris: Durand.

Jameson, Fredric. 1981. "On Interpretation: Literature as a Socially Symbolic Act." The Political Unconscious: Narrative as a Socially Symbolic Act, 17-102. Ithaca: Cornell University Press.

Karpinski, Gary. 1991. "The Interval Cycles in the Music of Bartók and Debussy through 1918." PhD. diss., City University of New York.

Kern, Stephen. 1983. The Culture of Time and Space: 1880-1918. Cambridge: Harvard University Press.

Klein, Michael. 2005. Intertextuality in Western Art Music. Bloomington: Indiana University Press.

Korsyn, Kevin. 1991. "Towards a New Poetics of Musical Influence." Music Analysis 10: 3-72.

- 2003. Decentering Music: A Critique of Contemporary Musical Research. Oxford: Oxford University Press.

Kurth, Ernst. 1968. Romantische Harmonik und die Krise in Wagners Tristan. Reprint, Hildesheim: G. Olms.

Lewin, David. 1987. Generalized Musical Intervals and Transformations. New Haven: Yale University Press.

Lorenz, Alfred. 1926. Tristan. Vol. 2 of Das Geheimnis der Form bei Richard Wagner. Berlin: M. Hasse.

Marder, Elissa. 2001. Dead Time: Temporal Disorders in the Wake of Modernity (Baudelaire and Flaubert). Stanford: Stanford University Press.

Marion, Gregory. 2001. "A Foreground Mist? Debussy's Brouillards." Current Musicology 66: 21-65.

- 2007. "Debussy and Recollection: trois aperçu." Music Theory Online 13, no. $1,<\mathrm{http} / / \mathrm{mto}$.societymusictheory.org/issues/mto.07.13.1/mto.07.13.1. marion.html> (accessed December 3, 2007).

McCreless, Patrick. 1991. "Syntagmatics and Paradigmatics: Some Implications for the Analysis of Chromaticism in Tonal Music." Music Theory Spectrum 14: 147-78.

McFarland, Mark. 2000. "Debussy and Stravinsky." Cahiers Debussy 24: 79-112.

Messing, Scott. 1988. Neoclassicism in Music: From the Genesis of the Concept Through the Schoenberg/Stravinsky Polemic. Ann Arbor: UMI Research Press.

Moevs, Robert. 1969. "Intervallic Procedures in Debussy: 'Serenade' from the Sonata for Cello and Piano 1915." Perspectives of New Music 8, no. 1: 82-101.

Orledge, Robert. 2003. "Debussy the Man." In The Cambridge Companion to Debussy, ed. S. Trezise, 9-24. Cambridge: Cambridge University Press.

Parks, Richard. 1989. The Music of Claude Debussy. New Haven: Yale University Press.

Reising, Russell. 2001. "An Interview with Tom Robbins." Contemporary Literature 42, no. 3: 463-484. 
Roberts, Paul. 1996. Image: The Piano Music of Claude Debussy. Portland, Oregon: Amadeus Press.

Rothgeb, John. 1995. "The Tristan Chord: Identity and Origin." Music Theory Online 1, no. 1, <http://mto.societymusictheory.org/issues/mto.95.1.1/mto.95.1.1.rothgeb.art> (accessed December 3, 2007).

Schoenberg, Arnold. 1975. Style and Idea: Selected Writings of Arnold Schoenberg. Edited by L. Stein. Translated by L. Black. Berkeley: University of California Press.

Straus, Joseph. 1990. Remaking the Past: Musical Modernism and the Influence of the Tonal Tradition. Cambridge: Harvard University Press.

Tatham, Campbell. 1971. "John Barth and the Aesthetics of Artifice." Contemporary Literature 12, no. 1: 60-73.

Ward, Patricia and Patty, James, eds. 2001. Baudelaire and the Poetics of Modernity. Nashville: Vanderbilt University Press.

Watkins, Glenn. 1994. Pyramids at the Louvre: Music, Culture, and Collage from Stravinsky to the Postmodernists. Cambridge: The Belknap Press of Harvard University Press.

White, Hayden. 1973. Metahistory: The Historical Imagination in NineteenthCentury Europe. Baltimore: The Johns Hopkins University Press.

- 1978. Tropics of Discourse: Essays in Cultural Criticism. Baltimore: The Johns Hopkins University Press.

\section{ABSTRACT}

This paper proposes that Mikhail Bakhtin's heteroglossia-the process of coming to know one's own language in the language of others-is evident in two of Debussy's compositions from Children's Corner, most directly in "Golliwogg's Cake-Walk" and more subtly in "Serenade for the Doll." In particular, "Serenade" collapses a number of historical horizons-some of these Wagnerian-as Debussy finds his own compositional path. Debussy's approach reflects the obsession La belle Epoque had with the past, and moreover with its need to keep the past alive while fashioning a future through the blending of multiple voices.

\section{RÉSUMÉ}

Cet article veut démontrer lévidence de l'hétéroglossie - processus de connaissance de sa langue maternelle par le biais d'autres langues - de Mikhail Bakhtin dans deux compositions tirées des Children's Corner de Debussy, à savoir le « Golliwogg's Cake-Walk» et, plus subtilement que dans le précédent, dans la "Serenade for the Doll ». La " Sérénade " comprime un certain nombre d'horizons historiques - certains wagnériens - au fil du développement d'un style original par Debussy. Son approche reflète l'obsession qu'entretient La belle Époque avec le passé dont elle ressent le besoin de conserver vivant tout en proposant un futur se retrouvant à travers le mélange de voix multiples. 